\title{
Lead concentrations in human tissues
}

\author{
P. S. I. BARRY and D. B. MOSSMAN \\ The Associated Octel Company Limited, London and Warrington Hospital Group
}

\begin{abstract}
Barry, P. S. I., and Mossman, D. B. (1970). Brit. J. industr. Med., 27, 339-351. Lead concentrations in human tissues. A study of 69 subjects at post-mortem, four of whom had histories of occupational exposure to lead, demonstrated a marked difference in the lead concentrations between bones and soft tissues.

The soft tissues of infants and young children contained low concentrations of lead, varying from $0.01 \mathrm{ppm}$ in muscle to $0.46 \mathrm{ppm}$ in liver. By the end of the second decade of life the concentrations of lead in most of the soft tissues showed values varying between $0.06 \mathrm{ppm}$ in muscle and $1.35 \mathrm{ppm}$ in liver and thereafter did not increase with advancing age.

The concentrations of lead in bone were considerably greater than those in the soft tissues, being about $1 \mathrm{ppm}$ in infants and young children and increasing to more than $40 \mathrm{ppm}$ in persons over the age of 50 years. Adult male bones contained more lead than adult females by a ratio of 3 to 2 , and in both sexes the long bone contained concentrations of lead two and a half times that observed in the flat bone. No marked difference was noted in lead concentrations between the corresponding soft tissues of the two sexes.

From the findings it appeared that in adults the total body burden varied widely from subject to subject. Nearly $95 \%$ was represented by the lead content in bone, of which more than $70 \%$ was in dense bone. A far lower concentration of lead was found in the bones of children than in those of adults, but there was less divergence in the lead concentrations in the soft tissues.

The total lead content in the soft tissues of the majority of the subjects investigated appeared to be relatively stable and did not correlate with levels in bone.

The four male subjects with known occupational exposure to lead had greater concentrations of lead in bone than those with no known occupational exposure, but no difference was noted in the soft tissues between the two groups, with the exception of the most heavily exposed subject in whom concentrations of lead in the brain were over $4 \mathrm{ppm}$ and in the aorta $28 \mathrm{ppm}$.

Hair and nails were found to contain relatively high concentrations of lead, approximately $20 \mathrm{ppm}$; some significance may be attached to this finding in a medico-legal context.

The findings of this study would suggest that the present intake of lead among the general population is no greater than in the past.
\end{abstract}

Probably more has been expounded about the effects of lead and its compounds on the human system, both actual and by inference, than about any other element. Saturnism has been described since the early days of recorded history. It was familiar to Greek, Roman and Arabian physicians before the Christian era. Hippocrates described lead colic in $370 \mathrm{BC}$ and Pliny (AD 23 to 79) reported poisoning in lead workers. Dioscorides (AD 100) knew of lead colic, paralysis and delirium. Repeated reference is made to it throughout the ages, as recorded in the writings of Sir George Baker in 1767 (The Devonshire Colic), Tanquerez Des Planches in 1839 (Treatise on Lead Poisoning) and Rumpelt in 1845 (On Lead and its Action on the Human Body) (McCord, 1953; Hunter, 1957). Ramazzini in 1713 
noted ill effects among potters who worked with lead. However, despite the wealth of information available on the subject, many questions remain open to argument, including the mode of activity and the concentrations which constitute a hazard to health.

Since it was demonstrated by Kehoe, Thamann, and Cholak (1933) that lead, previously thought not to be a normal constituent of the human body, was in fact a natural and inevitable component in the human system, by virtue of its ubiquitous presence in the earth's crust, a number of authorities in the field of environmental health and from other disciplines have posed questions about lead absorption from multiple sources and the effects that this may have on health.

Although, despite extensive investigation (Swiss Leaded Gasoline Commission Report to the Federal Council, 1961; Hofreuter, Catcott, Keenan, and Xintaras, 1961; Waller, Commins, and Lawther, 1965; U.S. Public Health Service, 1965; Everett, Day, and Reynolds, 1967), no positive evidence has been produced to show that present-day levels of lead in the environment constitute a hazard to health, there are those who have argued that the margin between good health and poisoning has been so reduced as to pose a threat to the populace from a condition of so-called 'Chronic Lead Insult', resulting in unrecognized incipient lead poisoning (Patterson, 1965; Danielsson, 1967). Furthermore, it has been stated that some sections of the community, children and pregnant women in particular, may be more suceptible to the effects of lead than others, and that a similar susceptibility may obtain in the case of some diseases (Moncrief, Koumides, Clayton, Patrick, Renwick, and Roberts, 1964; Hardy, 1965)

\section{Study outline}

The object of our study has been to determine lead concentrations in various tissues from among a population situated in the north-west of England. This is a densely populated area, with a history of increasing industrialization dating back for more than 100 years. Agricultural activities exist within the area, but the majority of our cases happen to fall within the urban group; most of those of the rural group have had industrial or urban types of occupations.

Potable water supplies to the area come from a number of sources, including wells and reservoirs, of varying plumbo-solvency, but which, for the most part, comply with the recommended standard of the World Health Organisation of a concentration of lead in potable water of not more than 0.05 part per million.

Our study covers the period from May 1966 to
December 1968. During this time we had the opportunity to examine the tissues from 73 post-mortems, of which 47 were males and 26 females, obtained from three Hospital Groups in the area. For the purpose of this report, we have excluded four of the male subjects from the series, as we were not able to obtain histories of occupation for them. This has reduced the male subjects in our reported series to 43 , of whom four had known histories of occupational exposure to lead. It is accepted that these numbers cannot be described as a comprehensive representation of a large group and for this reason we are continuing with our investigation. However, we believe that the information now available provides certain definitive trends in the pattern of lead distribution in the human organism, and as such may be of interest.

As our study progressed, certain tissues were found to be consistently low in lead content and were omitted from the series; these included the gastro-intestinal tract, muscle, fat and skin. Others, such as the gonads, ductless glands, aorta and hair and nails were included in the study as time went by. In a number of cases a complete set of the tissues that had been requested was not made available at the time of the post-mortem examination. As a result, for some tissues insufficient results were available for a calculated estimation of total body burden to be made with precision. To compensate for these omissions, certain assumptions have been made, as are explained later in the text, which we believe are consistent with probability.

Only a few urine samples were obtained, and the results on our blood samples may not represent the true picture of the blood lead content in life, due to haemolytic and fibrinolytic changes following death.

As wide an age distribution as was feasible was obtained. Apart from age distribution, and our desire to obtain a preponderance of males to females, no attempt was made to specify cases in any way. From the occupational histories made available, the majority of the subjects, apparently, did not experience unusual types of exposure to lead during life.

The preparation of samples and the analytical technique employed are described in the appendix.

\section{Results}

In the statistical analysis of the results, various aspects of our findings have been correlated, as between males and females, order of magnitude of lead concentrations in individual body tissues, age groups, and as assessment of the total body burden. There exists a very wide variation in lead concentrations in individual tissues, particularly bone, and to this extent the findings are unbalanced. However, it has still been possible to make certain inferences for both males and females. The first section of our 
report is concerned only with subjects who have had no known occupational exposure to lead.

\section{Non-occupational lead exposure}

Sex difference Although no marked variation was found between sexes in a comparison of the concentration of lead in the soft tissues (Table 1), a consistent difference was noted in the lead concentrations in the bones between the sexes, the males having a concentration some $30 \%$ higher than females. A similar observation was recorded by Nusbaum, Butt, Gilmour, and DiDio in 1965. In view of this difference, a total composite estimation of the lead concentrations in the combined tissues of males and females was not made.

Tissue lead concentrations The mean concentrations of lead in various tissues, recorded in parts per million on a wet weight basis, are outlined in Table
1 for both males and females. Bone is seen to contain a much higher concentration of lead than the soft tissues, and long bone (as represented by tibia) to have, on average, more than twice the concentration of flat bone (rib). These bone lead concentrations approximate quite closely to the mean values reported by Kehoe, of $6.5 \mathrm{ppm}$ in flat bone and $17.8 \mathrm{ppm}$ in long bone, in 1961 and 1962. The difference in concentrations between long and flat bone was noted also by Tompsett in 1936 .

The distribution of the frequencies of occurrence of lead in the bones of both male and female subjects is outlined in Table 2 . It is of interest to note that the frequency distribution of the lead content of the long bones of the males is biphasic. This suggests that the male subjects comprised two groups, of which one had experienced little exposure to lead during life and the other an increased level of exposure at some time during life, which might

TABLE 1

Tissue Lead CONCENTRATIONS (PPM WeT Weight): NoN-OCCuPational EXPOSURE

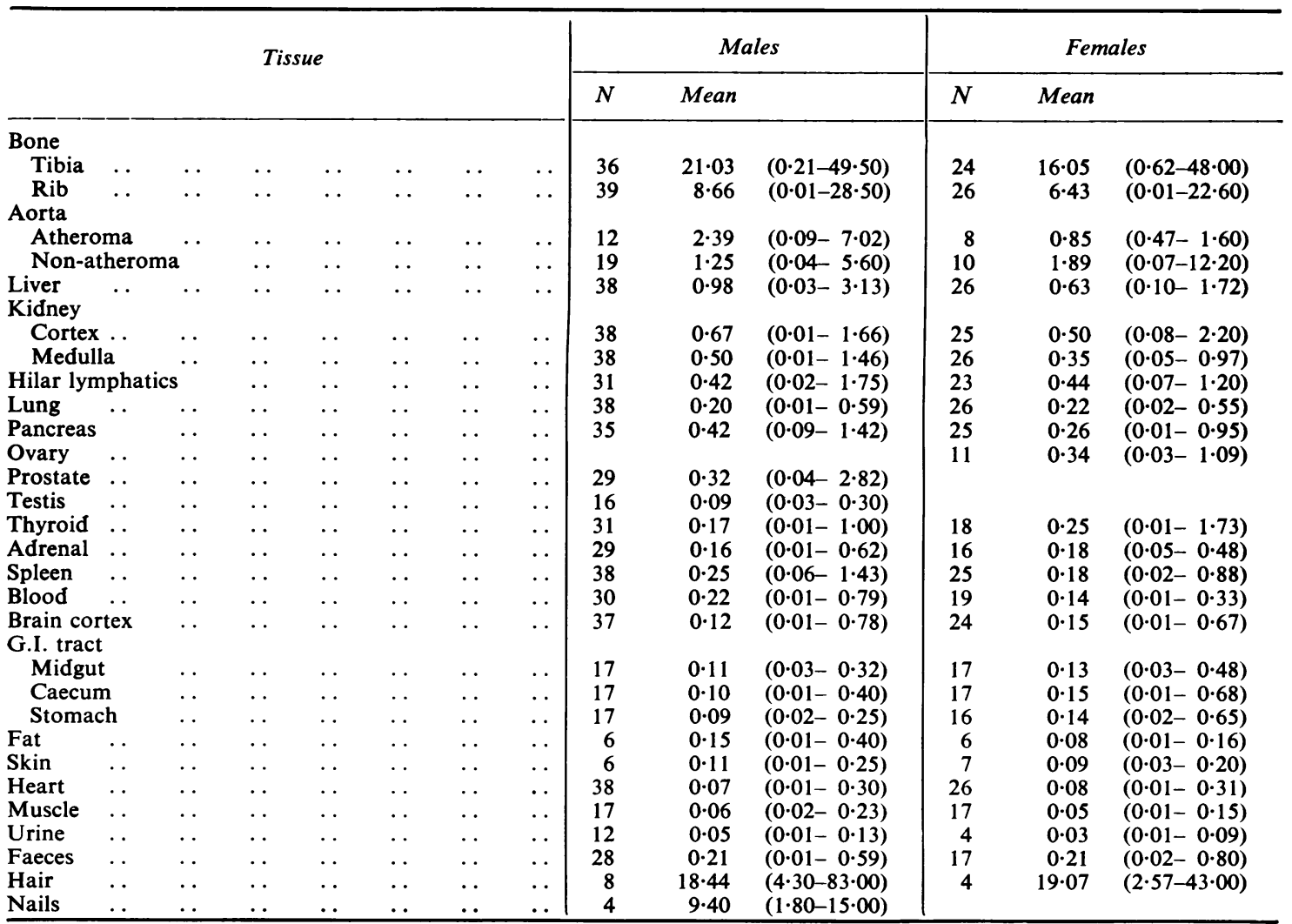

Faeces results reported as ppm ash weight.

$\mathrm{N}=$ no. of samples; ranges in parentheses. 
TABLE 2

Distribution of Frequencies of OCCURRENCE OF LEAD IN THE BONE OF SUbJeCtS WITH NO KNOWN OCCUPATIONAL EXPOSURE

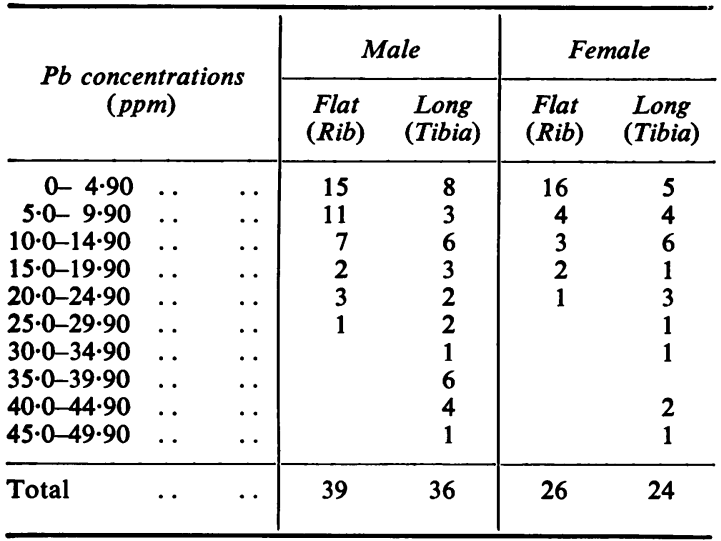

indicate that the activities of men with no recognized occupational exposure are such as to divide them into two distinct categories with respect to magnitude of exposure to lead, or that the opportunity for exposure to lead may have been greater in earlier years than at the present time. Eight of the 11 results of male long bone in excess of $35 \mathrm{ppm}$ were from men over the age of 50 years, but of the remaining 25 results of less than $35 \mathrm{ppm}$, only 7 were from men in this age group.

Among the soft tissues, the aorta contains the highest concentrations of lead, atheromatous areas containing somewhat more lead than non-atheromatous in males, but it was the reverse in females. The liver contains the next highest concentration and this is followed by the kidney. In both sexes the kidney cortex and medulla contain similar concentrations of lead. Allcroft (1951) found in bovine animals acutely poisoned by lead that the kidney cortex contained higher concentrations of lead than the medulla, but this difference was not noted in animals which had ingested smaller quantities of lead over a long period of time. An explanation may be that at toxic levels of exposure lead accumulates in the kidneys, for the most part in the region of the proximal convoluted tubules, the straight parts of which in animals extend for a greater length into the cortex (Goyer, personal communication, 1970).

In both sexes it was noted that the hilar lymphatic glands contained higher concentrations of lead than lung tissue, and of the other glands which were examined, the pancreas was found to contain a greater concentration of lead than the thyroid and the adrenal in males, but in females the concentra- tions were similar; in the sex glands, the lead concentration in the prostate was greater than the concentration in the testes, but approximated to the concentration in the ovary. The blood and the spleen showed a close similarity at relatively low concentrations, those in females being somewhat lower than in males; the brain, gastro-intestinal tract, heart, muscle, fat and skin showed the lowest concentrations of lead in all of the tissues that were examined.

Samples of hair and nails both showed higher concentrations of lead than any of the soft tissues; these findings will be considered later.

In Tables 3 and 4 our findings are set out on the basis of age groups.

Children Irrespective of sex, infants showed low lead concentration in all tissues. This finding was reported also by Kehoe in 1963. Bone showed the highest levels of individual tissues at approximately $1 \mathrm{ppm}$, but there appeared to be little difference between rib and tibia, which might be expected in view of the similarity of these two types of bone in young children.

Adults (a) Bone: The lead concentration in bone increased in both sexes with advancing age. This finding agrees with that of Nusbaum et al. (1965) and of Schroeder and Tipton (1968). The greater proportion of lead appeared in long bone, and in general the bones of male subjects, of both types, showed higher concentrations of lead than did those of female subjects. In Fig. 1 are recorded each individual result against the age of each subject for both males and females with $95 \%$ confidence limits in a straight line regression. The figures reveal that the increase of lead in bone with age, from about $8 \mathrm{ppm}$ at the age of 20 years to over $40 \mathrm{ppm}$ in the tibia at the age of 80 years in male subjects, is far from uniform, which suggests that the experience of these individuals in terms of exposure to lead varied widely in time and severity, the concentration of lead in the bones being dependent upon irregular absorption of lead in food and beverages, and in airborne lead inhaled during the course of various occupations at home or at work.

Schroeder and Tipton (1968) observed that after the fifth or sixth decade, in their subjects, bone lead concentrations 'levelled off' and then reduced after the seventh decade. Our findings do not support this observation of the American authors but rather seem to indicate that the longer life continues the more likelihood is there for lead to accumulate in bone, by virtue of the obvious greater opportunity of episodic exposure, or, on a cohort basis, that accelerated accumulation has occurred in the past, due to a greater opportunity for the absorption of lead from the environment of that time.

(b) Soft tissues: Most of the soft tissues that were 
TABLE 3

Age Groups-Males. Tissue Lead Concentrations (pPM wet wt) Non-occupational Exposure

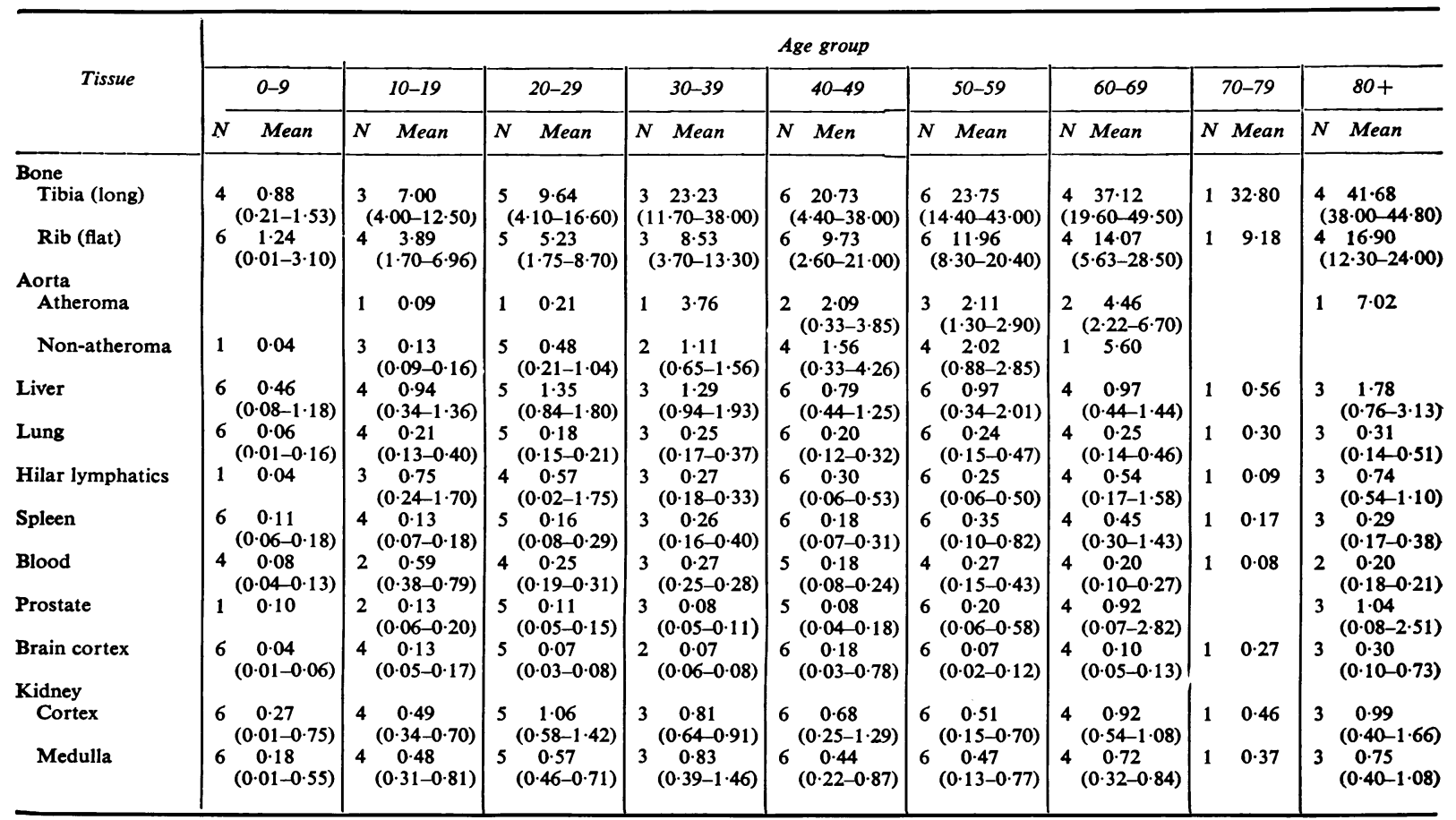

$\mathbf{N}=$ no. of samples; ranges in parentheses.

TABLE 4

Age Groups-Females. Tissue Lead Concentrations (pPM wet wt) Non-occupational Exposure

\begin{tabular}{|c|c|c|c|c|c|c|c|c|c|}
\hline \multirow{3}{*}{ Tissue } & \multicolumn{9}{|c|}{ Age group } \\
\hline & $0-9$ & $10-19$ & $20-29$ & $30-39$ & $40-49$ & $50-59$ & $60-69$ & $70-79$ & $80+$ \\
\hline & $N \quad$ Mean & & $N \quad$ Mean & & $N \quad$ Mean & $N \quad$ Mean & $N \quad$ Mean & $N \quad$ Mean & $N \quad$ Mean \\
\hline Bone & & & & & & & & & \\
\hline $\begin{array}{l}\text { Tibia (long) } \\
\text { Rib (flat) }\end{array}$ & $\left|\begin{array}{cc}2 & 0.98 \\
& (0.62-1.34) \\
4 & 1.10\end{array}\right|$ & $\begin{array}{l}\text { No } \\
\text { samples }\end{array}$ & \begin{tabular}{|cc}
3 & 4.27 \\
& $(2.50-6.30)$ \\
3 & 3.25
\end{tabular} & $\begin{array}{l}\text { No } \\
\text { samples }\end{array}$ & $\mid \begin{array}{cc}4 & 12 \cdot 81 \\
(1.50-22.00) \\
4 & 5 \cdot 42\end{array}$ & $\begin{array}{ll}2 & 14 \cdot 40 \\
(11 \cdot 70-17 \cdot 10) \\
2 & 6 \cdot 17\end{array}$ & $\mid \begin{array}{cc}6 & 20 \cdot 20 \\
(7 \cdot 71-44 \cdot 40) & \\
6 & 8.68\end{array}$ & $\begin{array}{|ll|}4 & 22.35 \\
(10.50-44.40) & 7 \cdot 57 \\
4 & 7.57\end{array} \mid$ & $\begin{array}{cc}3 & 26 \cdot 62 \\
(6.35-48.00) & \\
3 & 12.40\end{array}$ \\
\hline N10 (ilat) & $\begin{array}{cc}4 & (0.01-2 \cdot 71) \\
1 & 0 \cdot 11\end{array}$ & & $(2 \cdot 30-4 \cdot 75)$ & & $(2.30-10 \cdot 00)$ & $(3 \cdot 24-9 \cdot 10)$ & $\begin{array}{c}0.85-22.60) \\
10.98\end{array}$ & $\begin{array}{c}(3 \cdot 50-13 \cdot 10) \\
1 \quad 4 \cdot 11\end{array}$ & $(3 \cdot 60-17 \cdot 10)$ \\
\hline Atheroma & & & & & $\begin{array}{ll}1 & 0.90\end{array}$ & $\begin{array}{ll}1 & 0.97\end{array}$ & & & $\begin{array}{lc}2 & 1.04 \\
& (0.47-1.60)\end{array}$ \\
\hline Non-atheroma & & & $\begin{array}{lc}3 & 0.33 \\
& (0.07-0.64)\end{array}$ & & $\begin{array}{ll}1 & 0.88\end{array}$ & $1 \quad 0.69$ & & & $\begin{array}{cc}2 & 6 \cdot 83 \\
(1 \cdot 46-12 \cdot 20)\end{array}$ \\
\hline Liver & $\mid \begin{array}{lc}4 & 0.54 \\
& (0 \cdot 10-1.37)\end{array}$ & & $\begin{array}{lc}3 & 0.66 \\
& (0.51-0.77)\end{array}$ & & $\begin{array}{lc}4 & 0 \cdot 61 \\
& (0 \cdot 19-1 \cdot 10)\end{array}$ & $\begin{array}{lc}2 & 0.40 \\
& (0.39-0.41)\end{array}$ & \begin{tabular}{|cc}
6 & 0.78 \\
$(0 \cdot 23-1 \cdot 49)$
\end{tabular} & $\left|\begin{array}{cc}4 & 0.51 \\
& (0.33-0.71)\end{array}\right|$ & $\begin{array}{cc}3 & 0.80 \\
& (0 \cdot 20-1 \cdot 72)\end{array}$ \\
\hline Lung & $\begin{array}{lc}4 & 0.08 \\
(0.02-0.18)\end{array}$ & & $\begin{array}{cc}3 & 0.23 \\
(0.06-0.44)\end{array}$ & & $\begin{array}{lc}4 & 0 \cdot 23 \\
& (0 \cdot 18-0 \cdot 30)\end{array}$ & $\begin{array}{lc}2 & 0 \cdot 19 \\
& (0 \cdot 18-0 \cdot 20)\end{array}$ & $\begin{array}{cc}6 & 0.18 \\
(0.04-0.30)\end{array}$ & $\left|\begin{array}{cc}4 & 0.33 \\
& (0 \cdot 16-0.53)\end{array}\right|$ & $\begin{array}{lc}3 & 0.34 \\
& (0.20-0.50)\end{array}$ \\
\hline Hilar lymphatics & $\begin{array}{ll}1 & 0.41\end{array}$ & & $\begin{array}{ll}3 & 0.40 \\
(0.07-0.65) & \end{array}$ & & $\begin{array}{cc}4 & 0 \cdot 26 \\
(0 \cdot 10-0 \cdot 45)\end{array}$ & $\begin{array}{lc}2 & 0.39 \\
& (0.32-0.46)\end{array}$ & $\begin{array}{l}6 \quad 0.42 \\
(0.15-0.81)\end{array}$ & $\begin{array}{lc}4 & 0.71 \\
(0 \cdot 20-0.79)\end{array}$ & $\begin{array}{ll}3 \quad 0.47 \\
(0.35-0.64)\end{array}$ \\
\hline Spleen & \begin{tabular}{cc|}
4 & 0.08 \\
& $(0.02-0 \cdot 18)$
\end{tabular} & & $\begin{array}{cc}3 & 0.09 \\
& (0.06-0.14)\end{array}$ & & $\begin{array}{|cc|}3 & 0.12 \\
& (0.09-0.17)\end{array}$ & $\left|\begin{array}{cc}2 & 0.18 \\
& (0.07-0.28)\end{array}\right|$ & $\begin{array}{cc}6 & 0.17 \\
(0 \cdot 08-0.26)\end{array}$ & $\left|\begin{array}{cc}4 & 0.20 \\
& (0.07-0.39)\end{array}\right|$ & $\begin{array}{ll}3 & 0.44 \\
& (0.07-0.88)\end{array}$ \\
\hline Blood & $\begin{array}{lc}2 & 0.02 \\
& (0.01-0.03)\end{array}$ & & $\begin{array}{lc}3 & 0.15 \\
(0.04-0.32)\end{array}$ & & $\mid \begin{array}{cc}3 & 0.17 \\
& (0.06-0.23)\end{array}$ & $\begin{array}{ll}1 & 0 \cdot 10\end{array}$ & $\begin{array}{cc}5 & 0.16 \\
(0.04-0.33)\end{array}$ & $\left|\begin{array}{lc}3 & 0 \cdot 14 \\
(0.07-0 \cdot 26)\end{array}\right|$ & $2 \begin{array}{l}0.21 \\
(0.20-0.22)\end{array}$ \\
\hline Brain cortex & $\begin{array}{lc}3 & 0.03 \\
& (0.01-0.04)\end{array}$ & & $\begin{array}{lc}3 & 0.06 \\
& (0.04-0.07)\end{array}$ & & $\begin{array}{ll}4 & 0.07 \\
& (0.04-0.11)\end{array}$ & $\begin{array}{ll}1 & 0.07\end{array}$ & \begin{tabular}{|cc}
6 & 0.33 \\
$(0.05-0.67)$
\end{tabular} & $\left|\begin{array}{lc}4 & 0.10 \\
& (0 \cdot 06-0 \cdot 19)\end{array}\right|$ & $\begin{array}{ll}3 & 0.23 \\
(0.03-0.28)\end{array}$ \\
\hline $\begin{array}{l}\text { Kidney } \\
\text { Cortex }\end{array}$ & $4 \begin{array}{c}0 \cdot 10 \\
(0 \cdot 03-0 \cdot 22)\end{array}$ & & $\begin{array}{ll}3 & 0.81 \\
& (0.48-1 \cdot 35)\end{array}$ & & $4 \begin{array}{l}0.91 \\
(0 \cdot 37-2 \cdot 20)\end{array}$ & $\begin{array}{lc}2 & 0.55 \\
& (0.32-0.77)\end{array}$ & $\begin{array}{cc}5 & 0.44 \\
(0 \cdot 21-0.70)\end{array}$ & $\left|\begin{array}{cc}4 & 0.43 \\
& (0.30-0.68)\end{array}\right|$ & $3 \quad \begin{array}{c}0.35 \\
(0.10-0.63)\end{array}$ \\
\hline Medulla & $\left|\begin{array}{cc}4 & 0.07 \\
& (0.03-0.22)\end{array}\right|$ & & $\begin{array}{cc}3 & 0.66 \\
& (0.35-0.97)\end{array}$ & & \begin{tabular}{|cc}
4 & 0.35 \\
& $(0.25-0.44)$
\end{tabular} \mid & $\begin{array}{cc}2 & 0 \cdot 24 \\
& (0 \cdot 18-0.30)\end{array} \mid$ & $6 \begin{array}{c}0.44 \\
(0.14-0.77)\end{array}$ & $\left|\begin{array}{cc}4 & 0.37 \\
& (0.26-0.54)\end{array}\right|$ & $\begin{array}{ll}3 & 0.30 \\
& (0.11-0.57)\end{array}$ \\
\hline
\end{tabular}

$\mathbf{N}=$ no. of samples; ranges in parentheses. 

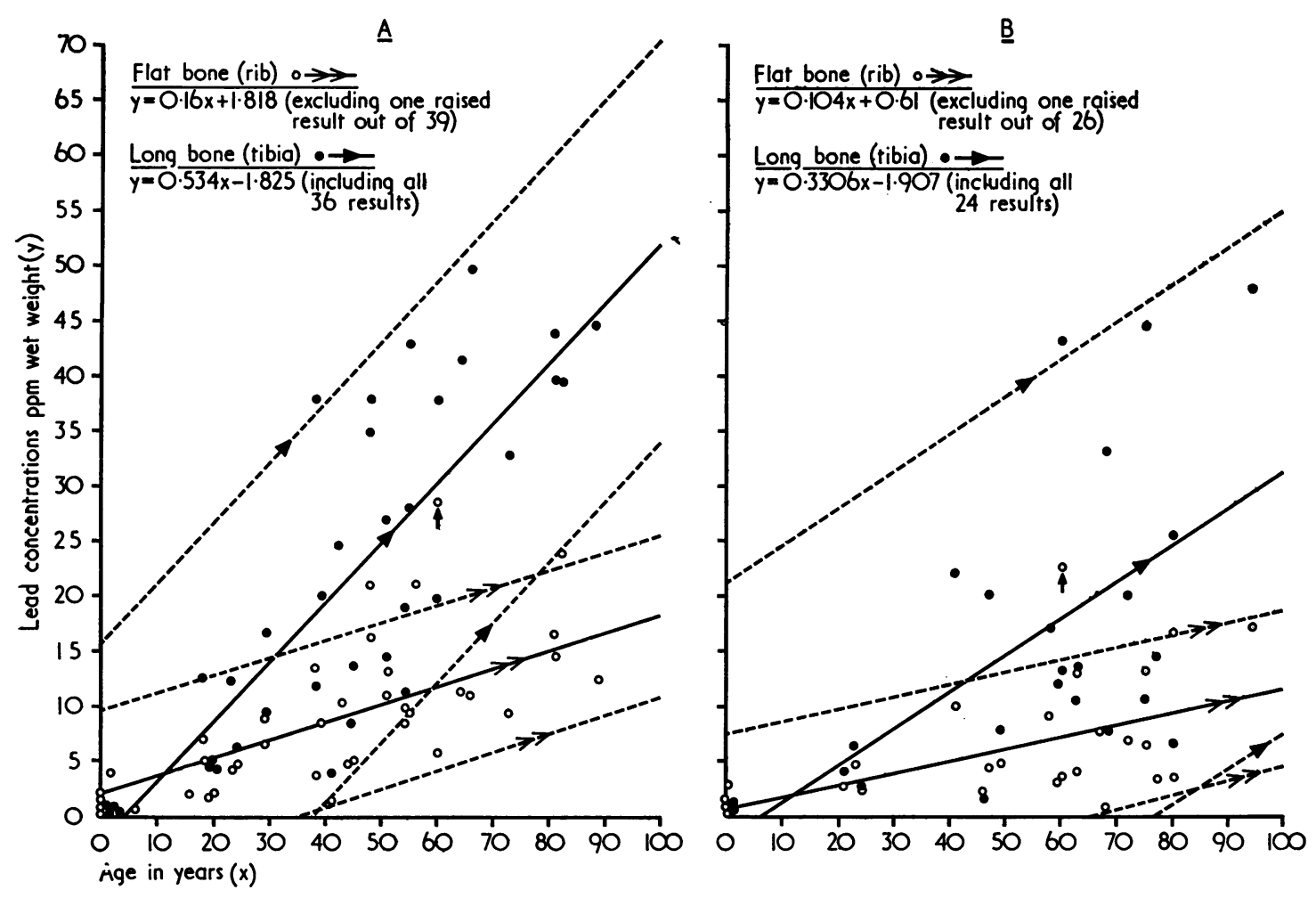

FIG. 1. Lead concentrations in bone-non-occupational exposure ( $95 \%$ confidence limits): (A) males, and (B) females.

examined showed no evidence of increase in lead concentration with age, after the second decade. The aorta, spleen and lung in both sexes showed increases of a low order of magnitude, not highly significant statistically (Figs. 2 to 4 ).

Total body burden The variability of lead concentrations found in bone results in estimated body burdens that are widely divergent from subject to subject, and within specific age groups. We have set out our findings in Table 6 on a basis of total body burden calculated from a table of organ percentage weights (Table 5), against a 'standard man' weight of $70 \mathrm{~kg}$, in which the skeletal weight is taken as one-seventh of the total (Schroeder and Tipton, 1968). It has been assumed that flat and long bones are of equal weight, proportional to the total skeleton.

As to soft tissues, where no result was available for a particular tissue, the average concentration of lead for that tissue, from the same age group of the particular subject, was substituted, or, failing this, the overall average concentration for that particular tissue was taken, as recorded in Table 1. Also, dense connective tissue was not examined, but as this would appear to contain a significant concentration of lead, a correction factor of approximately $10 \%$ of the soft tissues total was applied (Schroeder and Tipton, 1968). For purposes of comparison of total body burden, the same 'standard man' weight has been applied for both sexes and for children, as well as the body burden calculated from the actual weights of our subjects.

From the results in Table 6 it is evident that the mean total body burden of lead in adult males, of $174 \mathrm{mg}$, exceeded that of females by $33 \%$ on a 'standard man' basis. On a basis of actual weight the mean total body burden of adult males, calculated at $162 \mathrm{mg}$, exceeded that of females by $40 \%$. It is apparent that bone lead constituted the great bulk of the lead of the total body burden (nearly $95 \%$ on average for both sexes). The total lead in the soft tissues in both sexes is more constant in comparison with bone lead, which varies far more widely. This observation was noted by Kehoe in 1961. Overall, the adult male subjects demonstrated marginally higher levels of lead in soft tissues than did adult females. 


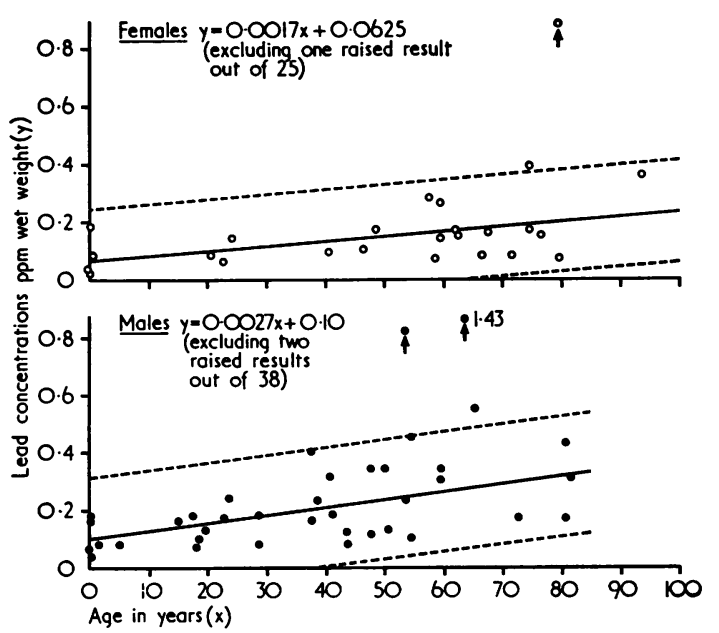

FIG. 2. Lead concentrations in spleen-non-occupational exposure $(95 \%$ confidence limits).

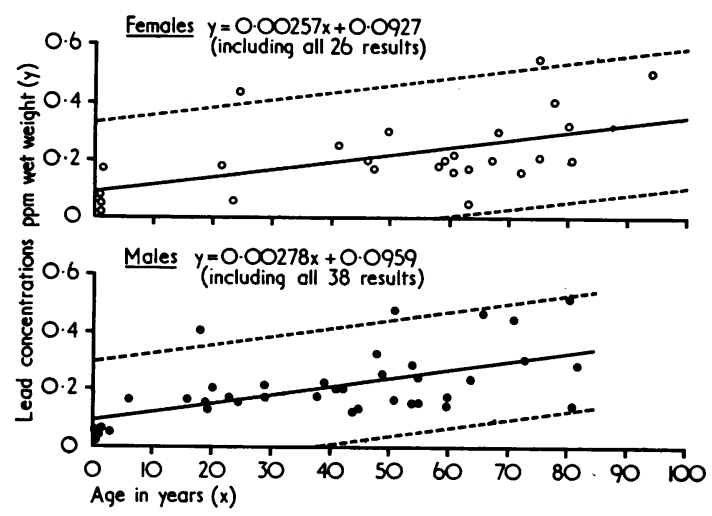

FIG. 3. Lead concentrations in lung - non-occupational exposure $(95 \%$ confidence limits).

For both the actual body burden of lead and the 'standard man' burden, the averages of bone and soft tissue weights are recorded against age in Table 7. These findings suggest an increase in bone lead level with age in both sexes; the soft tissue lead levels, on the other hand, appear to remain relatively stable and to be independent of age.

Soft tissue levels did not correspond well with bone levels, as between individual subjects.

Young children, of whom the 10 in our series were under the age of 6 years, in addition to containing low levels of lead in all tissues, contained a lower proportion of the total body burden in bone than did adults (Table 6), and showed little difference

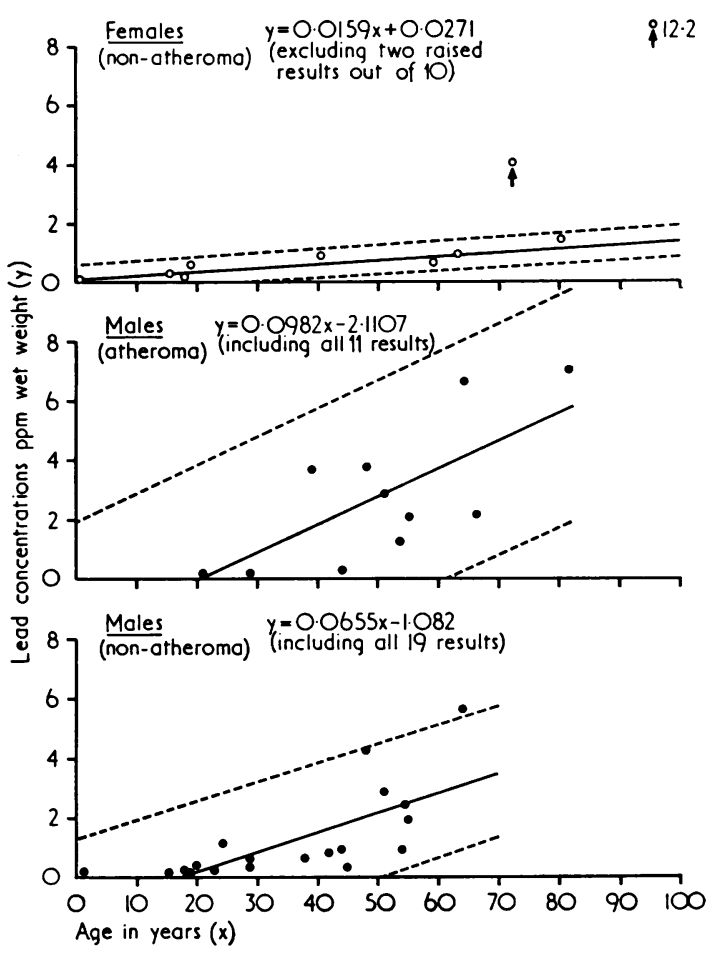

FIG. 4. Lead concentrations in aorta - non-occupational exposure $(95 \%$ confidence limits).

TABLE 5

\begin{tabular}{|c|c|}
\hline $\begin{aligned} \text { WeIGHT } & \text { Rati } \\
\text { 'StANDARD } & \text { MaN' }\end{aligned}$ & $\begin{array}{l}\text { OF ORGANS } \\
\text { (WEIGHT } 70 \quad \mathrm{~kg} \text { ) }\end{array}$ \\
\hline Tissue & $\%$ Body weight \\
\hline $\begin{array}{l}\text { Muscle } \\
\text { Fat } \\
\text { Skeleton } \\
\text { Blood } \\
\text { Skin } \\
\text { Dense connective tissue } \\
\text { Liver } \\
\text { Brain } \\
\text { G.I. tract } \\
\text { Lungs } \\
\text { Heart } \\
\text { Kidneys } \\
\text { Spleen } \\
\text { Pancreas } \\
\text { Aorta } \\
\text { Hair } \\
\text { Other }\end{array}$ & $\begin{array}{r}40 \cdot 00 \\
17 \cdot 85 \\
14 \cdot 30 \\
7 \cdot 86 \\
7 \cdot 00 \\
3 \cdot 29 \\
2 \cdot 57 \\
2 \cdot 04 \\
1 \cdot 71 \\
1 \cdot 43 \\
0.50 \\
0 \cdot 44 \\
0 \cdot 26 \\
0 \cdot 14 \\
0 \cdot 14 \\
0.02 \\
0 \cdot 45\end{array}$ \\
\hline Other & $100 \cdot 00$ \\
\hline
\end{tabular}

Taken from table of 'standard man' of Schroeder and Tipton (1968). 
TABLE 6

Total Body Burden (mg Pb): Non-occupational Exposure

\begin{tabular}{|c|c|c|c|c|c|c|c|c|c|}
\hline & \multicolumn{5}{|c|}{ Actual weight } & \multicolumn{4}{|c|}{ Standard man weight $70 \mathrm{~kg}$} \\
\hline & & $\begin{array}{c}\text { Total body } \\
\text { burden }\end{array}$ & $\begin{array}{c}\text { Soft } \\
\text { tissue }\end{array}$ & Bone & $\begin{array}{l}\text { Bone as } \\
\% \text { of } \\
\text { total }\end{array}$ & $\begin{array}{l}\text { Total body } \\
\text { burden }\end{array}$ & $\begin{array}{c}\text { Soft } \\
\text { tissue }\end{array}$ & Bone & $\begin{array}{c}\text { Bone as } \\
\% \text { of } \\
\text { total }\end{array}$ \\
\hline $\begin{array}{l}\text { Adult males (16 yr } \\
\text { and over) } \\
\text { Mean weight } 69.5 \mathrm{~kg}\end{array}$ & $\begin{array}{l}\text { Mean } \\
\text { Range }\end{array}$ & $\begin{array}{c}162 \cdot 19 \\
26 \cdot 60-352 \cdot 29\end{array}$ & $\begin{array}{c}(29 \text { subjects }) \\
9 \cdot 51 \\
5 \cdot 31-21 \cdot 10\end{array}$ & $\begin{array}{c}152 \cdot 68 \\
21 \cdot 04-340 \cdot 98\end{array}$ & $94 \cdot 14$ & $\begin{array}{c}173 \cdot 78 \\
34 \cdot 17-326 \cdot 81\end{array}$ & $\begin{array}{c}\text { (33 subj } \\
9 \cdot 31 \\
5 \cdot 46-23 \cdot 21\end{array}$ & $\begin{array}{l}\text { jects }) \\
164 \cdot 47 \\
27 \cdot 00-316 \cdot 33\end{array}$ & $94 \cdot 64$ \\
\hline $\begin{array}{l}\text { Adult females ( } 21 \mathrm{yr} \\
\text { and over) } \\
\text { Mean weight } 57 \cdot 7 \mathrm{~kg}\end{array}$ & $\begin{array}{l}\text { Mean } \\
\text { Range }\end{array}$ & $\begin{array}{c}112 \cdot 49 \\
18 \cdot 79-243 \cdot 70\end{array}$ & $\begin{array}{c}(20 \text { subjects) } \\
5 \cdot 65 \\
2 \cdot 62-8 \cdot 38\end{array}$ & $\begin{array}{c}106 \cdot 84 \\
12 \cdot 07-236 \cdot 64\end{array}$ & 94.98 & $\begin{array}{c}130 \cdot 84 \\
29 \cdot 52-338 \cdot 11\end{array}$ & $\begin{array}{c}(22 s u b) \\
6 \cdot 89 \\
4 \cdot 43-10 \cdot 56\end{array}$ & $\begin{array}{l}\text { jects }) \\
123 \cdot 95 \\
18 \cdot 96-328 \cdot 31\end{array}$ & $94 \cdot 76$ \\
\hline $\begin{array}{l}\text { Children ( } 6 \text { yr and } \\
\text { under, combined sexes) } \\
\text { Mean weight } 7 \cdot 5 \mathrm{~kg}\end{array}$ & $\begin{array}{l}\text { Mean } \\
\text { Range }\end{array}$ & $\begin{array}{c}1 \cdot 53 \\
0 \cdot 46-3 \cdot 11\end{array}$ & $\begin{array}{c}(10 \text { subjects }) \\
0 \cdot 55 \\
0 \cdot 12-1 \cdot 58\end{array}$ & $\begin{array}{c}0.99 \\
0.21-2.37\end{array}$ & 64.05 & $\begin{array}{c}15 \cdot 74 \\
6 \cdot 76-26 \cdot 55\end{array}$ & $\begin{array}{c}(10 \text { sub } \\
5 \cdot 23 \\
3 \cdot 32-9 \cdot 22\end{array}$ & $\begin{array}{c}\text { jects }) \\
10 \cdot 51 \\
3 \cdot 24-20 \cdot 26\end{array}$ & $66 \cdot 66$ \\
\hline
\end{tabular}

between the sexes (Table 7). When assessed on a 'standard man' weight basis the lead content of the soft tissues of the children approximated reasonably well to adult female 'standard man' soft tissues, 5.2 compared to $6.9 \mathrm{mg}$, but bone lead lagged far behind at 16 , compared to $131 \mathrm{mg}$. The lack of difference in lead concentrations observed in the tissues between the two sexes in young children is probably accounted for by the similarity of diet and environmental conditions at this early stage of life. The relatively high proportion of lead in soft tissue, compared to the lead levels in bone of young children, may be accounted for by the lack of hard, dense bone at this stage of life, which, when deve- loped in later life, appears to take up and retain lead. It is suggested that this may account, in some measure, for the adverse response of young children to severe lead exposure.

Our findings of total body burden of lead varied from the findings of Schroeder and Tipton (1968). On the basis of 'standard man' the total lead content in our female subjects corresponded reasonably well with the total body burden reported by these authors, but our male subjects contained approximately onethird more than theirs. In their report, the American investigators did not differentiate between the sexes and took rib, which we have found to contain significantly less lead than long bone (tibia), as represent-

TABLE 7

Total Body Burden (mg Pb) in Age Groups: Non-occupational Exposure

\begin{tabular}{|c|c|c|c|c|c|c|c|c|c|c|c|c|c|}
\hline \multirow{2}{*}{\multicolumn{2}{|c|}{ Age group }} & \multicolumn{6}{|c|}{ Mean actual weights } & \multicolumn{6}{|c|}{ Standard weight $(70 \mathrm{~kg})$} \\
\hline & & \multicolumn{3}{|c|}{ Bone } & \multicolumn{3}{|c|}{ Soft tissues } & \multicolumn{3}{|r|}{ Bone } & \multicolumn{3}{|c|}{ Soft tissues } \\
\hline & & $N$ & & Mean & $N$ & & Mean & $N$ & & Mean & $N$ & & Mean \\
\hline Males & $\begin{array}{r}0-9 \\
10-19 \\
20-29 \\
30-39 \\
40-49\end{array}$ & $\begin{array}{l}6 \\
4 \\
5 \\
3 \\
5\end{array}$ & $\begin{array}{r}0 \cdot 85 \\
45 \cdot 05 \\
76 \cdot 00 \\
168 \cdot 48 \\
156 \cdot 67\end{array}$ & $\begin{array}{l}(0.21-2 \cdot 37) \\
(21.04-88.27) \\
(32.46-157 \cdot 40) \\
(94.00-264.52) \\
(65.40-340.91)\end{array}$ & $\begin{array}{l}6 \\
4 \\
5 \\
3 \\
5\end{array}$ & $\begin{array}{r}0 \cdot 57 \\
11 \cdot 49 \\
9 \cdot 51 \\
10 \cdot 12 \\
10 \cdot 07\end{array}$ & $\begin{array}{l}(0 \cdot 15-1 \cdot 61) \\
(5 \cdot 56-21 \cdot 10) \\
(8 \cdot 01-13 \cdot 17) \\
(9 \cdot 62-10.94) \\
(7 \cdot 67-13 \cdot 01)\end{array}$ & $\begin{array}{l}6 \\
4 \\
5 \\
3 \\
6\end{array}$ & $\begin{array}{r}10 \cdot 60 \\
50 \cdot 11 \\
74 \cdot 19 \\
158 \cdot 50 \\
151 \cdot 97\end{array}$ & $\begin{array}{r}(3 \cdot 24-20 \cdot 26) \\
(27 \cdot 00-97 \cdot 10) \\
(29 \cdot 19-126 \cdot 23) \\
(76 \cdot 84-255 \cdot 96) \\
(34.93-294 \cdot 38)\end{array}$ & $\begin{array}{l}6 \\
4 \\
5 \\
3 \\
6\end{array}$ & $\begin{array}{r}5 \cdot 84 \\
12 \cdot 10 \\
9 \cdot 53 \\
9 \cdot 35 \\
6 \cdot 86\end{array}$ & $\begin{array}{l}(3 \cdot 53-9 \cdot 22) \\
(7 \cdot 15-23 \cdot 21) \\
(8 \cdot 24-11 \cdot 14) \\
(8 \cdot 47-10.94) \\
(5 \cdot 57-8 \cdot 62)\end{array}$ \\
\hline & $\begin{array}{l}50-59 \\
60-69 \\
70-79 \\
80+\end{array}$ & $\begin{array}{l}6 \\
3 \\
0 \\
3\end{array}$ & $\begin{array}{l}176 \cdot 70 \\
252 \cdot 08 \\
\\
256 \cdot 08\end{array}$ & $\begin{array}{l}(102 \cdot 74-350 \cdot 49) \\
(237 \cdot 11-266 \cdot 53) \\
(225 \cdot 59-306 \cdot 43)\end{array}$ & $\begin{array}{l}6 \\
3 \\
0 \\
3\end{array}$ & $\begin{array}{l}7 \cdot 96 \\
8 \cdot 27 \\
\\
9 \cdot 63\end{array}$ & $\begin{array}{l}(5 \cdot 31-11 \cdot 31) \\
(6 \cdot 43-10 \cdot 15) \\
(7 \cdot 20-13 \cdot 15)\end{array}$ & $\begin{array}{l}6 \\
4 \\
1 \\
4\end{array}$ & $\begin{array}{l}178 \cdot 17 \\
264 \cdot 21 \\
217 \cdot 98 \\
292 \cdot 26\end{array}$ & $\begin{array}{r}(97 \cdot 30-316 \cdot 33) \\
(226 \cdot 92-308 \cdot 73) \\
(280 \cdot 41-309 \cdot 35)\end{array}$ & $\begin{array}{l}6 \\
4 \\
1 \\
3\end{array}$ & $\begin{array}{r}8 \cdot 15 \\
8 \cdot 86 \\
8 \cdot 52 \\
10 \cdot 90\end{array}$ & $\begin{array}{l}(5 \cdot 46-10 \cdot 48) \\
(7 \cdot 86-9 \cdot 83) \\
(9 \cdot 39-13 \cdot 15)\end{array}$ \\
\hline Females & $\begin{array}{r}0-9 \\
10-19 \\
20-29 \\
30-39 \\
40-49\end{array}$ & $\begin{array}{l}4 \\
3 \\
3\end{array}$ & $\begin{array}{r}1 \cdot 19 \\
25 \cdot 12 \\
92 \cdot 82\end{array}$ & $\begin{array}{l}(0.42-1.88) \\
(21 \cdot 27-60 \cdot 15) \\
(12.07-159.66)\end{array}$ & $\begin{array}{l}4 \\
3 \\
3\end{array}$ & $\begin{array}{l}0.52 \\
5.47 \\
6.64\end{array}$ & $\begin{array}{l}(0.28-0.81) \\
(3.08-7.48) \\
(4.75-8.42)\end{array}$ & $\begin{array}{l}4 \\
3 \\
4\end{array}$ & $\begin{array}{r}10 \cdot 38 \\
37 \cdot 50 \\
90 \cdot 96\end{array}$ & $\begin{array}{l}(4 \cdot 91-18 \cdot 41) \\
(23 \cdot 95-55 \cdot 13) \\
(18 \cdot 96-159 \cdot 66)\end{array}$ & $\begin{array}{l}4 \\
3 \\
4\end{array}$ & $\begin{array}{l}4 \cdot 41 \\
6 \cdot 57 \\
7 \cdot 36\end{array}$ & $\begin{array}{l}(3 \cdot 34-6 \cdot 14) \\
(4 \cdot 85-7 \cdot 48) \\
(5 \cdot 01-10 \cdot 61)\end{array}$ \\
\hline & $\begin{array}{l}50-59 \\
60-69 \\
70-79 \\
80+\end{array}$ & $\begin{array}{l}2 \\
5 \\
4 \\
3\end{array}$ & $\begin{array}{l}106 \cdot 02 \\
117 \cdot 04 \\
113 \cdot 72 \\
166.98\end{array}$ & $\begin{array}{l}(81 \cdot 32-130 \cdot 72) \\
(27 \cdot 18-236 \cdot 64) \\
(58 \cdot 38-234 \cdot 73) \\
(36 \cdot 11-236 \cdot 23)\end{array}$ & $\begin{array}{l}2 \\
5 \\
4 \\
3\end{array}$ & $\begin{array}{l}5 \cdot 41 \\
5 \cdot 40 \\
4 \cdot 77 \\
5 \cdot 82\end{array}$ & $\begin{array}{l}(4.95-6.40) \\
(3.41-7.09) \\
(2.63-6.56) \\
(3.98-6.97)\end{array}$ & $\begin{array}{l}2 \\
6 \\
4 \\
3\end{array}$ & $\begin{array}{l}102 \cdot 63 \\
144.06 \\
149 \cdot 27 \\
194 \cdot 68\end{array}$ & $\begin{array}{l}(74 \cdot 54-130 \cdot 72) \\
(42 \cdot 71-328 \cdot 31) \\
(84 \cdot 82-286 \cdot 90) \\
(49 \cdot 65-324 \cdot 82)\end{array}$ & $\begin{array}{l}2 \\
6 \\
4 \\
3\end{array}$ & $\begin{array}{l}5 \cdot 41 \\
8 \cdot 09 \\
6 \cdot 17 \\
7 \cdot 00\end{array}$ & $\begin{array}{l}(4.95-5.87) \\
(5 \cdot 76-9.84) \\
(4.45-8 \cdot 02) \\
(5.47-9.58)\end{array}$ \\
\hline
\end{tabular}

$\mathbf{N}=$ no. of samples; ranges in parentheses. 
ing the total skeleton. The estimate of total lead in the soft tissues of our subjects appeared to be rather less than the estimate of Schroeder and Tipton.

Hair and nails On finding from the small number of subjects investigated in our post-mortem study that the lead content of hair and nails was relatively high (Table 1), we proceeded to collect samples of these tissues from a small group of living persons, together with urine specimens which were analysed for lead content to form a background control (Table 8). This group was composed of people with no known contact with lead and comprised both sexes, including children. No significant difference was noted in lead concentration between sexes and age groups or between the two tissues, but both showed lead concentrations, of about $20 \mathrm{ppm}$, which were considerably higher than the lead concentrations found in the soft tissues of our post-mortem subjects. Hair and nails would seem to be of some importance as an avenue of elimination of lead from the body, but as a very wide variation appears to exist in the concentrations observed between individuals, it is doubtful whether they would be of practical value for use in an assessment of occupational exposure, compared to the information provided by other laboratory tests, such as blood or urinary lead estimations. However, further study of this avenue of elimination of lead would be of interest, and could be of value in future medicolegal investigations, towards providing assistance in the determination of the severity of exposure, and the approximate time of occurrence, with respect to a particular situation in which lead may have been incriminated as a contributory factor of major importance.

Miscellaneous factors No difference was noted, in either males or females, in tissue lead concentrations as to area of residence, urban or rural. However, as has been indicated earlier, the area from which these subjects was drawn is primarily an industrial region in which rural residents have industrial or urban types of occupations. Nor was any difference noted between smokers and non-smokers. An attempt was made to correlate disease categories and lead concentrations in tissues, but no significant pattern of relationship emerged.

\section{Occupational lead exposure}

Among the group of post-mortem subjects investigated by us were four males, who from histories of occupation had been exposed to varying levels of lead. One of these was a plumber, one a miner and glass worker, one a worker in a wire producing factory, and one a worker in a white lead factory. Histories of illnesses among them did not reveal evidence of clinical lead intoxication. Three of these are considered as a group in Table 9, but the fourth (the white lead factory worker) is considered separately in Table 10, as the concentrations of lead in some of his tissues were raised to an extent where significant distortion would have resulted, had they been grouped with the tissues of the other three subjects.

In Table 9 a comparison is made between the lead concentrations in the tissues of the occupational exposure group and the group with no occupational

TABLE 8

Hair and Nails from Living Persons: Lead Concentrations

\begin{tabular}{|c|c|c|c|c|c|c|c|}
\hline & & \multicolumn{6}{|c|}{ Adults } \\
\hline & & \multicolumn{3}{|c|}{ Males } & \multicolumn{3}{|c|}{ Females } \\
\hline & & Hair & Nails & Urine & Hair & Nails & Urine \\
\hline $\begin{array}{l}\text { No. of samples } \\
\text { Mean (ppm) } \\
\text { Range .. }\end{array}$ & $\begin{array}{ll}. & \ldots \\
. & \ldots\end{array}$ & $\begin{array}{c}13 \\
15 \cdot 20 \\
2 \cdot 90-61 \cdot 90\end{array}$ & $\begin{array}{c}11 \\
18 \cdot 86 \\
3 \cdot 90-60 \cdot 00\end{array}$ & $\begin{array}{c}10 \\
0.027 \\
0.009-0.057\end{array}$ & $\begin{array}{c}8 \\
29 \cdot 25 \\
2 \cdot 90-69 \cdot 50\end{array}$ & $\begin{array}{c}4 \\
10 \cdot 85 \\
8 \cdot 60-13 \cdot 80\end{array}$ & $\begin{array}{c}3 \\
0.023 \\
0.009-0 \cdot 014\end{array}$ \\
\hline
\end{tabular}

\begin{tabular}{|c|c|c|c|c|c|c|c|c|}
\hline & & & \multicolumn{3}{|c|}{ Children } & \multirow{2}{*}{\multicolumn{3}{|c|}{ Total }} \\
\hline & & & \multicolumn{3}{|c|}{ Both sexes } & & & \\
\hline & & & Hair & Nails & Urine & Hair & Nails & Urine \\
\hline $\begin{array}{l}\text { No. of samples } \\
\text { Mean (ppm) } \\
\text { Range ... }\end{array}$ & $\begin{array}{l}. . \\
\ldots\end{array}$ & $\begin{array}{l}. \\
\cdots \\
.\end{array}$ & $\begin{array}{c}8 \\
19 \cdot 90 \\
7 \cdot 60-40 \cdot 00\end{array}$ & $\begin{array}{c}3 \\
35 \cdot 00 \\
28 \cdot 00-43 \cdot 00\end{array}$ & $\frac{\mathrm{Nil}}{-}$ & $\begin{array}{c}29 \\
20 \cdot 39 \\
2 \cdot 90-69 \cdot 50\end{array}$ & $\begin{array}{c}18 \\
19 \cdot 77 \\
3 \cdot 90-60 \cdot 00\end{array}$ & $\begin{array}{c}13 \\
0.026 \\
0.009-0.057\end{array}$ \\
\hline
\end{tabular}


exposure, all of whose ages ranged between 51 and 88 years.

It is evident from these findings that the mean lead concentrations in the bones of the occupationally exposed group of $59 \mathrm{ppm}$ in tibia and $36 \mathrm{ppm}$ in rib exceeded those of the non-occupationally exposed group of $33 \mathrm{ppm}$ in tibia and $14 \mathrm{ppm}$ in rib, but no marked difference was observed in the concentrations of lead in the soft tissues between the two groups.

The white lead worker (see Table 10) spent 43 years of his life (from age 22 to 65 ) employed at a factory, where, it is understood, the conditions of hygiene were not good. He retired from work at the age of 65 and died at the age of 82 from coronary thrombosis. Enquiry of relatives, after his death, did not reveal any history of significant illness during his life; yet at the time of his death, some 17 years after he had ceased to work, his bone lead concentrations were found to be of a high order, at $221 \mathrm{ppm}$ in tibia and $61 \mathrm{ppm}$ in rib, and the concentrations of lead in the brain and aorta were elevated at $4 \mathrm{ppm}$ and $28 \mathrm{ppm}$ respectively, but the remaining soft tissue concentrations, including kidney, were in no way dissimilar from the concentrations observed in the soft tissues of the group with no known history of occupational exposure to lead. Our findings as to the kidney, in this case and in our other occupationally exposed subjects where no increase in lead concentration was observed, do not seem to support the evidence of Radošević, Šarić, Beritić, and Knežević (1961) and Lane (1964), but rather confirm the conclusions of Tepper (1963).

In Table 11 an assessment has been made of the total body burden of lead of the occupationally exposed males, excluding the subject in Table 10, compared with the group of males with no known occupational exposure, within the same age range of over 50 years.

It is apparent that the mean lead content of the bones of the occupationally exposed group, of $482 \mathrm{mg}$, exceeded the mean lead content of the bones of those not occupationally exposed, of $222 \mathrm{mg}$, but little difference was apparent in the lead content, of approximately $8 \mathrm{mg}$, in the soft tissues of the two groups. 
TABLE 10

Most Heavily Exposed Subject: Tissue Lead CONCENTRATIONS

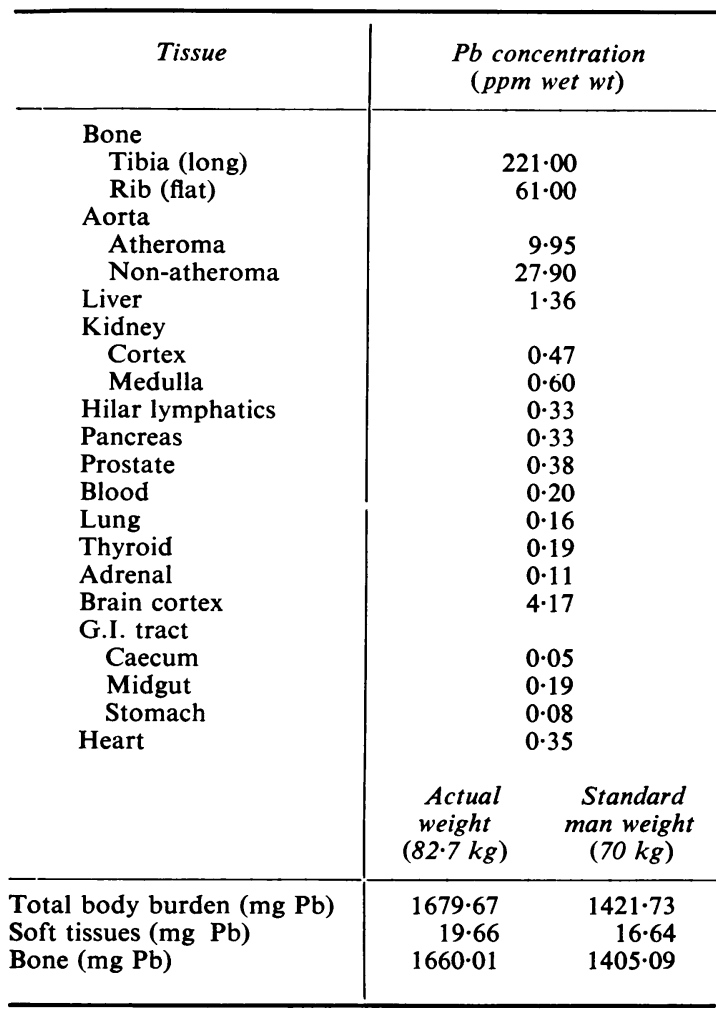

A more detailed study of the tissues of workers exposed to lead would be of interest in view of the suggestive findings we have at present, which seem to demonstrate the capacity of bone, particularly dense bone, to absorb and retain lead at unknown, but probably variable, rates over a long period of time. The subsequent release of lead from bone, if this occurs, would appear to be at such a rate as does not disturb the state of equilibrium in soft tissues.

\section{Discussion}

From our findings it is evident that in both sexes lead accumulates in the body with age, primarily in bone and principally in long or dense bone. It has been suggested that environmental factors, involving a greater availability of lead for absorption in earlier decades, may have accounted for the accumulation that has been noted. Marginal accumulation occurs in some of the soft tissues, but not in most of them. Bone, and in particular dense bone, appears to act as a reservoir for lead absorbed into the body, from which the rate of release is such as not to produce a significant change in soft tissue concentrations, which remain relatively constant irrespective of the level in bone, or of age after the second decade. Our findings do not support the contentions of Hardy (1966) that the mobilization of lead from the skeleton of the aging may be a cause for serious concern.

Young children contain less lead in their bones proportional to adults, and it has been surmised that probably this is due to a lack of dense bone in early life.

The bones in aduit males contain significantly higher concentrations of lead than those in females, but this difference is less obvious in the soft tissues of the two sexes. The difference between the sexes might be accounted for by the greater potential of the male to become exposed to lead materials during his normal mode of life, at home and at work, and to differences of habit in the consumption of food and drink.

The physiological capacity of human beings to control the absorption and retention of lead in the body would appear to be considerable. Man seems to be able to dispose of varying quantities of absorbed lead satisfactorily, without suffering illeffects.

TABLE 11

Group Comparisons: Total Body Burden (mg Pb) in Males Aged over 50

\begin{tabular}{|c|c|c|c|c|c|c|}
\hline \multirow{2}{*}{ Exposure } & \multicolumn{3}{|c|}{ Actual weight } & \multicolumn{3}{|c|}{ Standard man weight $(70 \mathrm{~kg})$} \\
\hline & $\begin{array}{c}\text { Total } \\
\text { body burden }\end{array}$ & Soft tissue & Bone & $\begin{array}{c}\text { Total } \\
\text { body burden }\end{array}$ & Soft tissue & Bone \\
\hline $\begin{array}{l}\text { Occupational } \\
\text { Mean } \\
\text { Range }\end{array}$ & $\begin{array}{c}3 \text { subj } \\
481 \cdot 73 \\
464 \cdot 59-501 \cdot 77\end{array}$ & $\begin{array}{c}\text { (mean weigh } \\
7.99 \\
4.95-12.53\end{array}$ & $\begin{array}{l}0.5 \mathrm{~kg}) \\
473 \cdot 91 \\
452 \cdot 85-495 \cdot 53\end{array}$ & $\begin{array}{c}480 \cdot 91 \\
431 \cdot 10-532 \cdot 92\end{array}$ & $\begin{array}{c}3 \text { subjects } \\
7 \cdot 82 \\
4.95-11 \cdot 62\end{array}$ & $\begin{array}{c}473 \cdot 09 \\
420 \cdot 12-526 \cdot 29\end{array}$ \\
\hline $\begin{array}{l}\text { Non-occupational } \\
\text { Mean } \\
\text { Range }\end{array}$ & $\begin{array}{c}12 s u b \\
222 \cdot 13 \\
108 \cdot 18-352 \cdot 29\end{array}$ & $\begin{array}{c}s \text { (mean weigh } \\
8.45 \\
5 \cdot 31-13 \cdot 15\end{array}$ & $\begin{array}{c}(5.9 \mathrm{~kg}) \\
213.68 \\
97 \cdot 47-340.98\end{array}$ & $\begin{array}{c}239 \cdot 72 \\
106 \cdot 00-326 \cdot 81\end{array}$ & $\begin{array}{c}15 \text { subjects } \\
9 \cdot 13 \\
5 \cdot 46-10 \cdot 48\end{array}$ & $\begin{array}{c}230 \cdot 59 \\
97 \cdot 30-316 \cdot 33\end{array}$ \\
\hline
\end{tabular}


The concentrations of lead in the tissues, and the total body burdens of lead, observed in our series of subjects are comparable to the findings reported by earlier investigators. Thus it would seem that the population at the present time is not being subjected to an overall greater exposure to lead, from a variety of sources, than in earlier decades. There is no evidence to suggest that the concentrations of lead in the ambient environment at the present time constitute a hazard to health, as has been implied in the sweeping use of the phrase 'chronic lead insult'.

We wish to acknowledge the work in this project of $\mathrm{Mr}$. E. Lowe and his staff at the Lostock Green biological laboratory of The Associated Octel Company Limited, who undertook the analysis of the tissues we examined, as well as Mr. J. Church and Mr. R. Ashton for their assistance in the compilation of our statistical information and Miss B. Baker for the provision of information on the case histories and occupations of the subjects investigated. We are indebted to Professor T. S. Scott and Mr. E. Moss of the Department of Occupational Health at the University of Manchester, and to Professor R. A. Kehoe of the Kettering Laboratory in the Department of Environmental Health, College of Medicine of the University of Cincinnati, for advice and encouragement. We wish to thank also the many others who assisted in the collection and preparation of our data.

\section{References}

Allcroft, R. (1951). Lead poisoning in cattle and sheep. Vet. Rec., 63, 583-590.

Danielsson, L. (1967). Gasoline containing lead. Report for the Swedish Royal Commission on Natural Resources, Solna, Sweden.

Everett, J. L., Day, C. L., and Reynolds, D. (1967). Comparative survey of lead at selected sites in the British Isles in relation to air pollution. Food Cosmet. Toxicol., 5, 29-35.

Goyer, R. A. (1970). Department of Pathology, Faculty of Medicine, University of North Carolina. Private communication.

Hardy, H. L. (1965). Lead: a review. U.S. Public Health Service Symposium on Environmental Health, pp. 73-83.

- (1966). What is the status of knowledge of the toxic effect of lead on identifiable groups in the population. Clin. Pharmacol. Ther., 7, 713-722.

Hofreuter, D. H., Catcott, E. J., Keenan, R. G., and Xintaras, C. (1961). The public health significance of atmospheric lead. Arch. environm. Hith, 3, 568-574.

Hunter, D. (1957). The Diseases of Occupations, 2nd ed., p. 219. The English Universities Press, London.

Kehoe, R. A. (1961). The Harben Lectures, 1960. The metabolism of lead in man in health and disease. J. roy. Inst. Publ. Hlth, 24, 81-96, 101-120, 129-143, and 177-203.

(1963). Industrial lead poisoning. In Industrial Hygiene and Toxicology, edited by Patty, F. A., 2nd rev. ed., vol. 20, pp. 941985. Interscience Publishers, New York.

- Thamann, F., and Cholak, J. (1933). On the normal absorption and excretion of lead. J. industr. Hyg., 15, 257-272.

Lane, R. E. (1964). Health control in inorganic lead industries. Arch. environm. Hith, 8, 243-250.

McCord, C. P. (1953). Lead and lead poisoning in early America: Benjamin Franklin and lead poisoning. Industr. Med. Surg., 22, 393-399.

Moncrieff, A. A., Koumides, O. P., Clayton, B. E., Patrick, A. D., Renwick, A. G. C., and Roberts, G. E. (1964). Lead poisoning in children. Arch. Dis. Childh., 39, 1-13.

Nusbaum, R. E., Butt, E. M., Gilmour, T. C., and DiDio, S. L. (1965). Relation of air pollutants to trace metals in bone. Arch. environm. Hlth, 10, 227-232.

Patterson, C. C. (1965). Contaminated and natural lead environments of man. Arch. environm. Hlth, 11. 344-360.
Radošević, Z., Šarić, M., Beritić, T., and Knežević, J. (1961). The kidney in lead poisoning. Brit. J. industr. Med., 18, 222-230.

Ramazzini, B. (1713). De Morbis Artificum Bernardini Ramazzini, Diatriba. Diseases of Workers: The Latin text of 1713. Revised; with Translation and Notes by W. C. Wright. Univ. Chicago Press, Chicago, 1940.

Schroeder, H. A., and Tipton, I. H. (1968). The human body burden of lead. Arch. environm. Hlth, 17, 965-978.

Swiss Leaded Gasoline Commission Report to the Federal Council (1961). Mitt. Geb. Lebensmittelunters. u. Hyg., 52, 135-244.

Tepper, L. B. (1963). Renal function subsequent to childhood plumbism. Arch. environm. Hlth, 7, 76-85.

Tompsett, S. L. (1936). The distribution of lead in human bones. Biochem. J., 30, 345-346.

U.S. Public Health Service (1965). Survey of Lead in the Atmosphere of Three Urban Communities. Division of Air Pollution. Publication No. 999-AP-12.

Waller, R. E., Commins, B. T., and Lawther, P. J. (1965). Air pollution in a city street. Brit. J. industr. Med., 22, 128-138.

World Health Organisation (1963). International Standards for Drinking-Water, 2nd ed. W.H.O., Geneva.

\section{APPENDIX}

Analytical method

\section{Sample preparation}

Bone Use 1-5 g

All adherent tissue must be removed and the sample washed in running distilled water. Subsequently place on soft paper tissue to remove all excess moisture and then weigh. Digest with about $5 \mathrm{ml}$ of nitric acid in a borosilicate dish on an electric hot plate to dryness. Cool and continue treating with further quantities of acid. Remove the last traces of carbon in the ash by heating in a muffle furnace for a few minutes at $450^{\circ} \mathrm{C}$.

To the cool white ash add $15 \mathrm{ml}$ of aqua regia (hydrochloric acid: nitric acid 3:1) and boil for a few minutes, add about $50 \mathrm{ml}$ of water and boil gently until no insoluble matter remains. Cool and transfer the solution quantitatively to a $100-\mathrm{ml}$ graduated flask and make up to volume with water and mix well. Use an aliquot of this solution for the lead determination.

\section{Soft tissue Use 5-30 g}

Wash the soft tissue under running distilled water, place on paper tissue to remove all excess moisture and then weigh. Place in a borosilicate glass dish, add $2.5 \mathrm{ml}$ per $10 \mathrm{~g}$ of sample of $50 \% \mathrm{w} / \mathrm{v}$ ammonium sulphate solution and an equal volume of nitric acid. Digest to dryness by heating on an electric hotplate. Allow to cool and repeat the heating with further quantities of nitric acid. After second or third digestion place the sample in a muffle furnace at $450^{\circ} \mathrm{C}$ for a few minutes. Continue the treatment until a white ash is produced or until there is no further change in the colour of the ash. Dissolve the ash in $15 \mathrm{ml}$ of aqua regia by the aid of gentle boiling, dilute with distilled water to about $50 \mathrm{ml}$ and allow to cool. Use this solution for the determination of lead.

Blood Recommended weight of sample $10-20 \mathrm{~g}$ Place the weighed sample in a borosilicate glass dish and heat carefully to dryness. Allow to cool and add $2.5 \mathrm{ml}$ per $10 \mathrm{~g}$ of sample of $50 \% \mathrm{w} / \mathrm{v}$ ammonium sulphate solution and $5 \mathrm{ml}$ of nitric acid. Proceed as for soft tissue.

Faeces Use the whole sample

Heat the sample in a borosilicate glass dish on a hot plate 
or in a muffle furnace at about $250^{\circ} \mathrm{C}$ until free of volatile matter. Cool and digest as described under bone. When the digestion is complete, allow the dish to cool and weigh it. Dissolve the ash as described under bone. Transfer the ash solution and any undissolved matter quantitatively to a $100-\mathrm{ml}$ graduated flask and make up to the $100 \mathrm{ml}$ mark with distilled water. Mix well and use a portion of this solution for the determination of lead. Allow the borosilicate dish to remain in a warm room until quite dry and then reweigh.

\section{Hair and nails Use 1-2 g}

Weigh the sample into a flat bottom borosilicate dish, add about $5-10 \mathrm{ml}$ of a solution and add a further quantity of detergent. Again carefully pour off the solution and wash free of detergent by decantation with several portions of distilled water. Continue as for soft tissue.

\section{Technique}

Preparation of reagents

(a) Hydrochloric acid and nitric acid are prepared leadfree by distillation in an all borosilicate glass still.

(b) Ammonium citrate, ammonium sulphate; hydroxylamine hydrochloride and potassium cyanide solutions are rendered lead-free by making alkaline with ammonia solution and extracting with dithizone in chloroform solution. The excess dithizone is then removed by repeated extraction with chloroform. Potassium phthalate solution is used as prepared, but a lead determination on the reagents is made along with each batch of samples.
Method

The sample solution is treated with ammonium citrate, potassium cyanide and sufficient ammonia to make the mixture alkaline. If iron is present in the sample, hydroxylamine hydrochloride is also added. The lead is extracted from this solution by means of dithizone in chloroform. Lead, bismuth, univalent thallium and divalent tin are the only metals extracted under these conditions. The presence of bismuth can be detected by the colour of the dithizone extract. Tin will have been removed from solution by oxidation in the preparation of the sample. Thallium is unlikely to be present and is assumed to be absent.

The lead is stripped from the dithizone by means of a phthalate buffer solution of $p H 3.4$. In the absence of bismuth, the dithizone returns to its original green colour. If bismuth is present, it will remain in the dithizone layer, giving a dull red to orange coloration. The aqueous layer is shaken once more with dithizone, to ensure complete removal of bismuth. Ammonia-cyanide solution and standard dithizone in chloroform solution are then added, and the lead is extracted from the aqueous phase. After allowing the layers to separate completely, the chloroform layer is transferred to an optical cell of a spectrophotometer and the optical density at a wavelength of $510 \mathrm{~nm}$ is then measured.

This is related to lead content by means of a calibration curve obtained by determinations carried out on standard amounts of lead.

Received for publication September 2, 1969 